Article

\title{
Survey, Identification, and Pathogenicity of Ceratocystis fimbriata Complex Associated with Wilt Disease on Acacia mangium in Malaysia
}

\author{
Samsuddin Ahmad Syazwan 1,2 1 , Ahmad Mohd-Farid 1,*, Wan-Azhar Wan-Muhd-Azrul ${ }^{3}$, \\ Hishamuddin Muhammad Syahmi ${ }^{1,2}$, Abdullah Mohd Zaki ${ }^{4}$, Su Ping Ong ${ }^{5}$ and Rozi Mohamed ${ }^{2}(\mathbb{D}$ \\ 1 Mycology and Pathology Branch, Forest Biodiversity Division, Forest Research Institute Malaysia, \\ Kepong 52109, Selangor, Malaysia; ahmadsyazwan@frim.gov.my or gs50910@student.upm.edu.my (S.A.S.); \\ syahmi@frim.gov.my (H.M.S.) \\ 2 Forest Biotechnology Laboratory, Department of Forest Science and Biodiversity, \\ Faculty of Forestry and Environment, Universiti Putra Malaysia, Serdang 43400, Selangor, Malaysia; \\ rozimohd@upm.edu.my \\ 3 Horticulture Research Centre, Malaysian Agricultural Research \& Development Institute (MARDI), \\ Persiaran MARDI-UPM, Serdang 43400, Selangor, Malaysia; wmazrul@mardi.gov.my \\ 4 Tree Improvement Programme, Forest Biotechnology Division, Forest Research Institute Malaysia, \\ Kepong 52109, Selangor, Malaysia; zaky@frim.edu.my \\ 5 Forest Entomology Branch, Fauna Biodiversity Programme, Forest Biodiversity Division, \\ Forest Research Institute Malaysia, Kepong 52109, Selangor, Malaysia; ongsuping@frim.gov.my \\ check for \\ * Correspondence: mohdfarid@frim.gov.my; Tel.: +60-362-797-119
} updates

Citation: Syazwan, S.A.; Mohd-Farid, A.; Wan-Muhd-Azrul, W.-A.; Syahmi, H.M.; Zaki, A.M.; Ong, S.P.; Mohamed, R. Survey, Identification, and Pathogenicity of Ceratocystis fimbriata Complex Associated with Wilt Disease on Acacia mangium in Malaysia. Forests 2021, 12, 1782. https://doi.org/ $10.3390 /$ f12121782

Academic Editor: Roberto Faedda

Received: 14 November 2021 Accepted: 3 December 2021 Published: 16 December 2021

Publisher's Note: MDPI stays neutral with regard to jurisdictional claims in published maps and institutional affiliations.

Copyright: (c) 2021 by the authors. Licensee MDPI, Basel, Switzerland. This article is an open access article distributed under the terms and conditions of the Creative Commons Attribution (CC BY) license (https:/ / creativecommons.org/licenses/by/ $4.0 /)$.

\begin{abstract}
Ceratocystis wilt disease surveys were conducted in three selected Malaysian Acacia mangium plantations. These completed surveys revealed the occurrence of the wilt disease, with the incidence of infection ranging from $7.5 \%$ to $13.6 \%$. Signs of wood-boring insects, bark peeling due to squirrel activity, and pruning wounds were often associated with this disease. The fungus most frequently isolated from the diseased trees was the Ceratocystis fungus. The analysis on the morphological characteristics has identified the fungus as Ceratocystis fimbriata complex. Phylogenetic analysis based on the sequences of the ITS, and concatenated sequences of EF $1 \alpha-\beta T$ regions grouped the isolates within the $C$. fimbriata sensu stricto, in comparison to other $C$. fimbriata isolates. Pathogenicity tests were conducted on six to nine-month-old healthy A. mangium seedlings by inoculating these seedlings with eight out of the 16 isolates. The results demonstrated that all the isolates were pathogenic, with mortality beginning as early as two weeks after inoculation. However, an ANOVA test indicated a significant difference between the pathogenicity levels among the fungal isolates. The results also showed that pathogen aggressiveness was not correlated with geographical origin. A host range test was also conducted by using C. fimbriata SSB3 and FRIM1162 isolates against several forest plantation species. The findings suggested that only A. mangium was susceptible to C. fimbriata. The other species remained healthy with no symptoms of infection even after seven weeks of treatment, as compared to the A. mangium species, where between 38 to $60 \%$ of the inoculated plants had died. This study provides new information on the status of Ceratocystis wilt disease, especially on the occurrence and effects on A. mangium plantation, by giving insights on how to control and manage this ferocious plant pathogen in the future.
\end{abstract}

Keywords: disease occurrence; plant pathogen; forest plantation; disease susceptibility

\section{Introduction}

Malaysia has approximately 700,000 ha of forest plantations that are planted mainly with Acacia mangium. Out of this, 312,000 of the plantations are established in Sarawak [1], while the remaining 200,000 ha and 187,805 ha are found in Sabah and Peninsular Malaysia, respectively [2]. More than ten private companies, with most of them operating in Sarawak, 
are actively planting $A$. mangium as a material to produce wood chips and veneers that cater to domestic and international markets. Most of these plantations are presently in their second rotation. Besides A. mangium, other fast-growing species, such as Aquilaria malaccensis, Eucalyptus grandis, E. pellita, Eucalyptus spp., Falcataria moluccana, Hevea brasiliensis (timber clones), Khaya ivorensis, Neolamarckia cadamba, Octomeles sumatrana, and Tectona grandis, are also planted across the country [3]. The most severe disease encountered in the A. mangium plantations was the red root rot disease associated with Ganoderma spp.; however, up until now, the condition has remained unresolved.

Unfortunately, another type of disease, the Ceratocystis wilt disease, has lately arisen as a severe threat to $A$. mangium crops, particularly in Indonesia and Vietnam [4]. Initially, the wilt disease was a significant danger to the Acacia plantations in Indonesia [5]. So, to counter the threats of Ceratocystis wilt disease and Ganoderma root rot, approximately 600,000 ha of A. mangium plantations in the country have been converted into Eucalyptus pellita and its hybrids [6]. A recent study in Vietnam reported that this pathogen had infected over 1000 ha of its $A$. mangium plantations [7]. Information on the incidence of this disease in Malaysian A. mangium plantations is still scarce. Still, in 2010, Ceratocystis wilt disease was identified in around $40 \%$ of the studied regions in Sabah, indicating that Malaysia is not spared from this debilitating situation [8]. Recent surveys for the wilt disease that were conducted in several A. mangium plantations in Sabah revealed that the incidence of infection varied from between $6 \%$ to $60 \%$ [9].

Infected trees can be identified through the observations of phyllodes wilting and drying, bark discolouration, gum exudation, cankers on infected stems, as well as the mortality of the plants [10]. Fungal pathogens, named C. manginecans and C. acaciivora, were first isolated and identified from diseased stems of infected A. mangium in Indonesia based on morphology characteristics and DNA sequences analyses [7,10]. Subsequently, $C$. manginecans seemed to be synonymous with $C$. fimbriata $[7,11]$. Ceratocystis manginecans, isolated from mango and Acacia, resembles the Brazilian C. fimbriata populations according to the revelation by using phylogenetic analyses [12]. This fungus has been linked to significant crop losses, especially for mango species in Brazil [13], Pakistan [14], and Oman [15], pomegranate (Punica granatum) in India [16], and coffee in Latin America [17]. Others affected crop species include Dalbergia sissoo [14], Eucalyptus spp. and Hevea brasiliensis [18].

This pathogen requires wounds on the surfaces of the plant to cause infection $[19,20]$. In addition, the most common spreading mechanism of this disease is through spore dispersal (endoconidia, aleurioconidia, chlamydospores, and ascospores), followed by insect vector activity and mechanical transmission [21]. Although the disease spread is often associated with soil contaminated with fungal spores [22,23], the disease is also spread through other mechanisms, for example, rain splash and contaminated insect frass, which is easily carried over by the wind [24]. Moreover, a recent report revealed that the fungal asexual stage could also be dispersed through wind-borne conidia [21].

Generally, there is a dearth of published information about the Ceratocystis wilt disease in Malaysian A. mangium plantations, especially in the Peninsula and Sarawak. As shown in Indonesia and Vietnam, the significant susceptibility of A. mangium to Ceratocystis may pose a severe threat to the local plantation industry. Most critically, this disease may spread to other forest plantation species and commercially valuable crops, including oil palms, rubber, and fruit trees. In light of this, wilt disease surveys were conducted in selected A. mangium plantations in Malaysia. Thus, the objectives of the study are (1) to investigate the incidence of wilted $A$. mangium trees in Malaysian plantations; (2) to determine the causal agent(s) of this disease, and (3) to assess the threat of the identified fungal pathogen (s) against selected forest plantation species. The findings from this study would benefit foresters and plantation managers to plan for appropriate disease management strategies. 


\section{Materials and Methods}

\subsection{Disease Surveys}

Disease surveys were conducted between April 2015 and December 2016 in three A. mangium plantations located in various Malaysian states, namely Pahang, Johor, and Sarawak, with plantation sizes of 61 ha, 35,226 ha and 3000 ha, respectively. All the surveyed plantations have been planting A. mangium trees since 2009 and are currently on their second rotation. The average diameter at breast height (DBH) for the A. mangium trees was $7.4 \mathrm{~cm}, 8.2 \mathrm{~cm}$, and $13.4 \mathrm{~cm}$ for the plantings sampled in Pahang, Johor, and Sarawak, respectively. The surveyed spacing for each plantation was set as $3 \times 3 \mathrm{~m}^{2}$ rows. No fertiliser or fungicide was applied on these plantations.

Surveys in plantations were carried out in three random compartments with trees showing wilting and canker symptoms. One line transects were constructed for every compartment, with each measuring $100 \mathrm{~m}$ in length. The lines were placed at approximately $25 \mathrm{~m}$ from the edge of the compartment and 20 to $30 \mathrm{~m}$ between the lines. Each line transects had five points spaced at $25 \mathrm{~m}$ between each point. At each point, five trees (located up to approximately $5 \mathrm{~m}$ to the left and right of the line) were inspected from ground level to $1.5 \mathrm{~m}$ in height to find stem and branch symptoms associated with wilt disease. A total of 50 trees along each transect were examined.

Disease symptoms that were recorded ranged from canopy appearance (i.e., wilting, yellowing, drying of leaves or defoliation) and black discolouration on the exterior of the stem, as well as cracks or cankers on the branches and stems. Various observations were also recorded, including the presence of animal damage, insects, insect frass and boreholes, gummosis, and dark liquid oozing from stem wounds. The abundance of insect holes was categorised as: low (0-10 holes), moderate (11-20 holes), and high (21 and more). Additional information, such as spacing, rotation, seed source, when and whether pruning was being conducted, age of seedlings during planting, and fertiliser or pesticide application, were also recorded.

\subsection{Insect Trapping}

Insect traps were set up in the Pahang plantation due to the relatively higher incidence of wood-boring insects observed during the survey than the incidence of insects in the Sarawak and Johor plantations. Two Lindgren funnel traps [25] and six plastic bottlemodified traps [26] were used. A small plastic bag containing $10 \mathrm{~mL}$ of $99 \%$ alcohol was suspended in the middle of the trap to serve as an attractant. The traps were set up in April 2018, and observations were made at every fortnight for two months. Trapped insects were collected for identification at the Entomology Laboratory, Forest Research Institute of Malaysia (FRIM).

\subsection{Fungal Isolation and Identification}

Ten A. mangium trees exhibiting the disease-like symptoms were sampled from each of the three participating plantations. Diseased stems of the symptomatic trees were excised with a surface-sterilised machete. The bark was first removed, and longitudinal strips of wood (approximately $0.5 \mathrm{~cm}$ thick and around 10 to $15 \mathrm{~cm}$ long) were cut from the stained xylem. In some cases, diseased trees were also felled and were cut into several sections measuring between 10 and $20 \mathrm{~cm}$ in length. The samples were then placed into large plastic bags before being transported to the Mycology and Pathology Laboratory, FRIM. The samples were stored at $4{ }^{\circ} \mathrm{C}$ prior to fungal isolation.

Fungal isolation was carried out by using the carrot baiting method [27]. Pieces of the diseased stem, approximately $10 \mathrm{~cm}$ long (L) $\times 3 \mathrm{~cm}$ wide $(\mathrm{W}) \times 5 \mathrm{~mm}$ thick $(\mathrm{T})$, were placed between two slices of fresh carrot and incubated in a moist chamber at room temperature $\left(25 \pm 2{ }^{\circ} \mathrm{C} ;>80 \% \mathrm{RH}\right)$ for four to six days. A single pale orange ascospore mass, which appeared at the apex of the perithecium, was then picked with a sterile syringe needle and transferred into a Petri dish plated with $2 \%(w / v)$ Difco ${ }^{\circledR}$ malt extract agar (MEA) (BD Diagnostics, Franklin Lakes, NJ, USA) and incubated for four to six days. Four 
to five isolates from ten successfully isolated Ceratocystis from different diseased trees were selected to represent each surveyed plantation. Then, the selected isolates were catalogued with FRIM isolates number (Table 1) and used in this study. For comparison purposes, three Ceratocystis sp. isolates (SSB1, SSB2, and SSB3) from Tawau, Sabah, were obtained from Tawau, Sabah, courtesy of Sabah Softwood Ltd.

Table 1. List of Ceratocystis fimbriata used in this study.

\begin{tabular}{|c|c|c|c|}
\hline Origin & Host & Isolate No. & $\begin{array}{l}\text { GenBank Accession No. } \\
\text { (ITS, EF1- } \alpha \text { and } \beta \text { T)/Isolates }\end{array}$ \\
\hline \multirow{10}{*}{ Pahang, Malaysia } & \multirow{10}{*}{ Acacia mangium } & \multirow{3}{*}{ FRIM1157 } & MF522235 \\
\hline & & & MN296235 \\
\hline & & & MN296234 \\
\hline & & & MF522237 \\
\hline & & \multirow[t]{3}{*}{ FRIM1161 } & MN296236 \\
\hline & & & MN296219 \\
\hline & & & MF522238 \\
\hline & & \multirow{3}{*}{ FRIM1162 } & MN296237 \\
\hline & & & MN296220 \\
\hline & & & MF522236 \\
\hline \multirow{18}{*}{ Johor, Malaysia } & \multirow{18}{*}{ A. mangium } & \multirow{3}{*}{ FRIM1193 } & MN296244 \\
\hline & & & MN296227 \\
\hline & & & MF522245 \\
\hline & & \multirow[t]{3}{*}{ FRIM1169 } & MN296242 \\
\hline & & & MN296225 \\
\hline & & & MF522246 \\
\hline & & \multirow{3}{*}{ FRIM1170 } & MN296243 \\
\hline & & & MN296226 \\
\hline & & & MF522247 \\
\hline & & \multirow{3}{*}{ FRIM1244 } & MN296245 \\
\hline & & & MN296228 \\
\hline & & & MF522248 \\
\hline & & \multirow[t]{3}{*}{ FRIM1245 } & MN296246 \\
\hline & & & MN296229 \\
\hline & & & MF522249 \\
\hline & & \multirow{3}{*}{ FRIM1246 } & MN296247 \\
\hline & & & MN296230 \\
\hline & & & MF522239 \\
\hline \multirow{9}{*}{ Sarawak, Malaysia } & \multirow{9}{*}{ A. mangium } & \multirow{3}{*}{ FRIM1163 } & MN296238 \\
\hline & & & MN296221 \\
\hline & & & MF522240 \\
\hline & & \multirow[t]{2}{*}{ FRIM1164 } & MN296239 \\
\hline & & & MN296222 \\
\hline & & \multirow{4}{*}{ FRIM1165 } & MF522241 \\
\hline & & & MN296240 \\
\hline & & & MN296223 \\
\hline & & & MF522242 \\
\hline \multirow{12}{*}{ Sabah, Malaysia } & \multirow{12}{*}{ A. mangium } & \multirow[t]{3}{*}{ FRIM1166 } & MN296241 \\
\hline & & & MN296224 \\
\hline & & & MF522243 \\
\hline & & \multirow{3}{*}{ SSB1 } & MN296248 \\
\hline & & & MN296248 \\
\hline & & & MN296231 \\
\hline & & & MF522244 \\
\hline & & SSB2 & MN296249 \\
\hline & & & MN296232 \\
\hline & & & MF522233 \\
\hline & & SSB3 & MN296250 \\
\hline & & & MN296233 \\
\hline
\end{tabular}


Morphological identification was conducted according to [15,28-30] by using an Olympus BX61 compound microscope and an Olympus SZX10 Stereo Microscope (Olympus Corporation, Tokyo, Japan) equipped with image analyser systems, analySIS docu 5.0 (Olympus Soft Imaging Solutions GmbH, Münster, Germany) and Q-Capture Pro 7 (ver. 7.0.5) (QImaging Inc., Bogart, GA, Canada), respectively. The characteristics and structures of the culture, such as perithecium, ostiolar hyphae, ascospore, aleuriconidia, and conidia (barrel-shaped and cylindrical-shaped) $(\mu \mathrm{m})$ of all the fungal isolates were measured and described. At least 25 measurements were made for each structure of each isolate.

\subsection{Fungal Culture}

For DNA-based identification, single spore cultures were prepared from each of the fungal isolates on Difco ${ }^{\circledR}$ potato dextrose agar (PDA) (BD Diagnostics, Franklin Lakes, NJ, USA) according to standard protocols [31]. Five discs (4 $\mathrm{mm}$ diameter) were cut from the margin of actively growing five-day-old culture and transferred into a $250 \mathrm{~mL}$ conical flask containing $100 \mathrm{~mL}$ Difco ${ }^{\circledR}$ potato dextrose broth (BD Diagnostics, Franklin Lakes, NJ, USA). The flasks were then placed and shaken on an orbital shaker at $150 \mathrm{rpm}$ for 7 days at room temperature $\left(28 \pm 1^{\circ} \mathrm{C}\right)$. Mycelia were harvested from the flasks by filtration through a sterilised Whatman ${ }^{\circledR}$ Grade 1 filter paper (Sigma Aldrich, St. Louis, MO, USA) and immediately frozen in liquid nitrogen. All the $C$. fimbriata isolates (Table 1), including three fungal isolated from Sabah (SSB1, SSB2 \& SSB3), were used for the pathogenicity test. The cultures were grown on PDA, and 7-days-old cultures were cut out by using a $5 \mathrm{~mm}$ borer and stored in $20 \%$ glycerol solution at $-80^{\circ} \mathrm{C}$ for further use.

\subsection{DNA Extraction, PCR, and Phylogenetic Analysis}

Freeze-dried mycelia of the fungus were pulverised, lyophilised, and ground to a fine powder form. A total of $100 \mathrm{mg}$ materials were used for DNA extraction. The DNA extraction was carried out by using the DNeasy Plant Mini kit according to the manufacturer's protocol (Qiagen, Germany). Multiregions consisting of the internal transcribed spacer

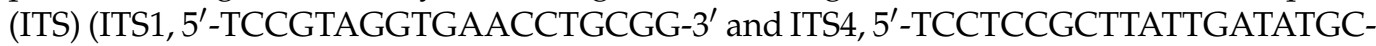
$\left.3^{\prime}\right)$ [32], elongation factor 1-alpha $(\mathrm{EF} 1 \alpha)\left(\mathrm{EF} 1 \mathrm{~F}, 5^{\prime}\right.$-TGCGGTGGTATCGACAAGCGT-3' and EF2R, 5'-AGCATGTTGTCGCCGTTGAAG-3') [33], and beta-tubulin ( $\beta \mathrm{t})\left(\mathrm{Bt} 1 \mathrm{a}, 5^{\prime}\right.$ TTCCCCCGTCTCCACTTCTTCATG-3 ${ }^{\prime}$ and Bt1b, 5' -GACGAGATCGTTCA-TGTTGAACTC$3^{\prime}$ ) [34] were amplified by using GeneAmp PCR System 9700 (Applied Biosystem, Waltham, MA, USA). The final volume of a PCR sample was $25 \mu \mathrm{L}$ and contained $12.5 \mu \mathrm{L}$ of $2 \mathrm{X}$ PCRBio Taq Mix Red (PCR Biosystem, London, UK), while the remaining volume consisted of $0.4 \mu \mathrm{M}$ of forward and reverse primers, $10 \mathrm{ng}$ of DNA template and molecular grade water. As for the negative control, the DNA template was replaced with sterilised distilled water to verify the absence of contaminants. The amplification processes of ITS, EF $1 \alpha$, and $\beta \mathrm{t}$ were programmed by following [35-37] protocols, respectively. The resultant PCR products were separated in $1 \%(w / v)$ agarose gel with $1 \mathrm{X}$ Tae buffer $(90 \mathrm{mM}$ Tris-acetate and 2 nM EDTA, pH 8.0), followed by staining with $0.01 \%(v / v)$ GelRed $^{\circledR}$ (Biotium, CA, USA) and documentation by using Gel Doc XR+ (Bio-Rad, Hercules, CA, USA) to assess the quality and presence of the amplified products. The verified PCR products were then sent to the FRIM Genetic Laboratory for Sanger DNA sequencing using the same set of primers stated previously.

Several Ceratocystis spp. from prior researches were chosen and compared with the DNA sequences sequenced from this current study (Table 2). Before phylogenetic analysis, each set or region sequence was aligned using MUSCLE [38] and concatenated using FaBox 1.5 alignment joiner [39]. Partition homogeneity test was conducted on the combined sequence by using PAUP [40] with a $p$-value of $>0.05(=0.07)$ (data not shown). Prior maximum-likelihood (ML) analysis was carried out by using PhyML [41], while the best-fit model test was conducted by using jModelTest2 [42]. Two phylogenetic trees were constructed by using the ML method and Bayesian analysis. ML method was 
carried out with 500 bootstrap replications and analysed based on the HKY85 substitution model [43]. Bayesian analysis was conducted by using MrBayes version 3.2 [44] with $1,000,000$ generations and the Markov Chain Monte-Carlo algorithm (MCMC) with four chains and sampled for every 1000th tree. The generated trees were viewed by using FigTree [45]. In this study, Huntiella chlamydoformis, Davidsoniella virescens, and Pestalotiopsis distincta were used as the outgroups.

Table 2. List of Ceratocystis spp. isolates from previous studies used as a reference in current investigation.

\begin{tabular}{|c|c|c|c|c|c|}
\hline $\begin{array}{l}\text { Ceratocystis } \\
\text { Species }\end{array}$ & Host & Origin & Isolate No. & $\begin{array}{c}\text { GenBank Accession No. (ITS, } \\
\text { EF1- } \alpha \text { and } \beta \text { T)/Isolates }\end{array}$ & References \\
\hline \multirow{4}{*}{ C. albifundus } & \multirow{4}{*}{ Acacia mearnsii } & \multirow{4}{*}{ South Africa } & \multirow{3}{*}{ CMW4068 } & DQ520638 & \multirow{3}{*}{ [46] } \\
\hline & & & & EF070400 & \\
\hline & & & & EF070429 & \\
\hline & & & \multirow{3}{*}{ CMW5329 } & AF388947 & \multirow{3}{*}[46]{} \\
\hline \multirow[t]{2}{*}{ C. albifundus } & \multirow[t]{2}{*}{ A. mearnsii } & \multirow[t]{2}{*}{ South Africa } & & EF070401 & \\
\hline & & & & DQ371649 & \\
\hline \multirow{3}{*}{ C. cercfabiensis } & \multirow{3}{*}{ Eucalyptus sp. } & \multirow{3}{*}{$\begin{array}{l}\text { Guangdong, } \\
\text { China }\end{array}$} & \multirow{3}{*}{ CMW42736 } & KP727583 & \multirow{3}{*}{ [47] } \\
\hline & & & & KP727625 & \\
\hline & & & & KP727600 & \\
\hline \multirow{2}{*}{ C. cercfabiensis } & \multirow{2}{*}{ Eucalyptus sp. } & \multirow{2}{*}{$\begin{array}{c}\text { Guangdong, } \\
\text { China }\end{array}$} & \multirow{2}{*}{ CMW42741 } & KP727586 & \multirow{2}{*}{ [47] } \\
\hline & & & & $\begin{array}{l}\text { КР727626 } \\
\text { КР727601 }\end{array}$ & \\
\hline \multirow{4}{*}{ C. fimbriata s.s. } & & & & AF264904 & \\
\hline & Ipomaea batatas & rapua New & CMW1547 & EF070395 & [48] \\
\hline & & & & EF070443 & \\
\hline & & & & EF190963 & \\
\hline C. fimbriatomima & Eucalyptus sp. & Venezuela & CMW24174 & EF190957 & [49] \\
\hline & & & & EF190951 & \\
\hline & & & & AY953384 & \\
\hline C. manginecans & Mangifera indica & Oman & CMW13852 & EF433318 & {$[49,50]$} \\
\hline & & & & EF433309 & \\
\hline & & & & EF433302 & \\
\hline C. manginecans & M. indica & Pakistan & CMW23634 & EF433320 & [15] \\
\hline & & & & EF433311 & \\
\hline & & & & EF433303 & \\
\hline C. manginecans & M. indica & Pakistan & CMW23628 & EF433321 & [15] \\
\hline & & & & EF433312 & \\
\hline & & & & FJ200256 & \\
\hline Ceratocystis sp. & M. indica & Brazil & CMW27306 & FJ200282 & [51] \\
\hline & & & & FJ200269 & \\
\hline & & & & FJ200258 & \\
\hline Ceratocystis sp. & M. indica & Brazil & CMW28908 & FJ200284 & [51] \\
\hline & & & & FJ200271 & \\
\hline & & & & EU881906 & \\
\hline C. larium & Styrax benzoin & Indonesia & CMW25434 & EU881900 & [52] \\
\hline & & & & EU881894 & \\
\hline & & & & EU881907 & \\
\hline C. larium & Styrax benzoin & Indonesia & CMW25435 & EU881901 & [52] \\
\hline & & & & EU881895 & \\
\hline & & & & AY233868 & \\
\hline C. papillata & Annona muricata & Colombia & CMW8857 & EU241483 & [49] \\
\hline & & & & AY233878 & \\
\hline & & & & AY177238 & \\
\hline C. papillata & Coffea arabica & Colombia & CMW10844 & EU241481 & [49] \\
\hline & & & & AY177229 & \\
\hline & & & & KC691475 & \\
\hline C. paradoxa & Carpophilus & South Africa & CMW37311 & KC691523 & [37] \\
\hline & & & & KC691499 & \\
\hline & & & & EU426554 & \\
\hline C. platani & Platanus sp. & Greece & CMW23918 & EF070397 & [53] \\
\hline & & & & EF070426 & \\
\hline
\end{tabular}


Table 2. Cont.

\begin{tabular}{|c|c|c|c|c|c|}
\hline $\begin{array}{l}\text { Ceratocystis } \\
\text { Species }\end{array}$ & Host & Origin & Isolate No. & $\begin{array}{c}\text { GenBank Accession No. (ITS, } \\
\text { EF1- } \alpha \text { and } \beta \text { T)/Isolates }\end{array}$ & References \\
\hline C. polychroma & $\begin{array}{l}\text { Syzygium } \\
\text { aromaticum }\end{array}$ & Indonesia & CMW11424 & $\begin{array}{l}\text { AY528970 } \\
\text { AY528978 } \\
\text { AY528966 } \\
\text { AY528971 }\end{array}$ & [46] \\
\hline C. polychroma & S. aromaticum & Indonesia & CMW11436 & $\begin{array}{l}\text { AY528979 } \\
\text { AY528967 } \\
\text { AY907030 }\end{array}$ & [46] \\
\hline C. smalleyi & Carya cordiformis & USA & C684 & $\begin{array}{c}\text { MG980734 } \\
\text { MG980830 } \\
\text { EF070420 }\end{array}$ & [54] \\
\hline C. smalleyi & Carya sp. & USA & CMW14800 & $\begin{array}{l}\text { EF070408 } \\
\text { EF070436 }\end{array}$ & [15] \\
\hline C. tsitsikammensis & $\begin{array}{l}\text { Rapaneae } \\
\text { melanophloeos }\end{array}$ & South Africa & CMW14276 & $\begin{array}{l}\text { EF408555 } \\
\text { EF408576 } \\
\text { EF408569 } \\
\text { EF408557 }\end{array}$ & [55] \\
\hline C. tsitsikammensis & Ocotea bullata & South Africa & CMW14280 & $\begin{array}{l}\text { EF408578 } \\
\text { EF408571 } \\
\text { EF070421 }\end{array}$ & [55] \\
\hline C. variospora & Quercus alba & USA & CMW20935 & $\begin{array}{l}\text { EF070409 } \\
\text { EF070437 } \\
\text { EU245002 }\end{array}$ & [15] \\
\hline C. zombamontana & Eucalyptus sp. & Malawi & CMW15235 & $\begin{array}{l}\text { EU244934 } \\
\text { EU244974 } \\
\text { EU245000 }\end{array}$ & [56] \\
\hline C. zombamontana & Eucalyptus sp. & Malawi & CMW15236 & $\begin{array}{l}\text { EU244932 } \\
\text { EU244972 }\end{array}$ & {$[56]$} \\
\hline
\end{tabular}

\subsection{Pathogenicity Test}

Pathogenicity tests against eight $C$. fimbriata isolates were conducted on 6- to 9-monthold A. mangium seedlings within 60 to $70 \mathrm{~cm}$ height range that are grown in $12^{\prime \prime} \times 12^{\prime \prime}$ poly bags in a greenhouse $\left(29 \pm 5{ }^{\circ} \mathrm{C} ;>80 \% \mathrm{RH}\right)$. All the $A$. mangium seedlings were collected from the same provenance in the FRIM campus. A total of twelve seedlings were inoculated with each of the $C$. fimbriata isolates. Before inoculation, the phyllodes and stem of each seedling were carefully examined to ensure that they were undamaged and disease-free. The inoculation point on the stem was surface sterilised by wiping the surface with a cotton wool pad dipped in $75 \%$ ethanol. An angled cut measuring approximately $1 \mathrm{~cm}(\mathrm{~L}) \times 0.4 \mathrm{~cm}(\mathrm{~W}) \times 0.3 \mathrm{~cm}(\mathrm{~T})$ was then made by using a sterile scalpel on the stem exterior $20 \mathrm{~cm}$ above the soil surface. A $4 \mathrm{~mm}$ disc of five-day-old C. fimbriata was carefully placed onto the cut surface by using a sterile scalpel tip. Negative control plants were wounded, followed by inoculation with a $4 \mathrm{~mm}$ disc of sterile MEA media, and immediately sealed with parafilm (Sigma Aldrich, St. Louis, MO, USA). The plants were watered twice daily, and the observations for disease development were recorded once a week for over a period of five weeks.

All the seedlings were harvested 35 days post-inoculation. To re-isolate fungi, the margin of lesions in the stem-wood samples was excised and either plated onto MEA or placed between two carrot slices. The cultures were subsequently incubated in a damp chamber for between 3 to 5 days before the re-identification process.

\subsection{Host Range Test}

Five popular forest plantation species, namely, Aquilaria malaccensis, A. mangium, Khaya ivorensis, Hevea brasiliensis, and Tectona grandis, and a medicinal plant, Eurycoma longifolia, were tested to confirm the host range of wilt disease pathogen. The plants were obtained 
from the FRIM and other local nurseries within the Sungai Buloh vicinity in the state of Selangor. The plants for testing were with a range height of $90 \mathrm{~cm}$ to $120 \mathrm{~cm}$ and appeared asymptomatic, meaning that the plants were not affected previously with diseases. Prior to the inoculation, the plants were re-potted in new $45 \times 60 \mathrm{~cm}^{2}$ polybags that contained a mixture of soil, peat, and sand in a 3:2:1 ratio. The plants were left in the shade house for two months and watered twice daily, once in the morning and once in the afternoon. Two fungal isolates, FRIM1162 and SSB3, were selected for inoculation against the seedlings. These two isolates were chosen because they were the most aggressive isolates among other studied isolates against $A$. mangium seedlings, as determined in the previous tests. The strains were also ascertained as the representatives of fungal pests from the Peninsula and Borneo. Fifteen seedlings of each species were artificially inoculated to validate the data for this study, according to the method described in the pathogenicity test. The investigation was performed in triplicates.

\subsection{Statistical Analysis}

All the plants in the pathogenicity test and host range tests were arranged in a completely randomised design (CRD). Mean mortality (\%) of inoculated A. mangium seedlings in the pathogenicity test, as well as the measurement of morphological characteristics and spores of different studied isolates, were calculated and analysed by using Tukey's test with $p$-value $(<0.05)$. Meanwhile, the survivability of selected inoculated forest plantation species in the host range test was measured using Waller-Duncan's test through SAS $^{\circledR}$ Studio release 3.5 (SAS Institute, Inc., Cary, NC, USA) software. Subsequently, the mean of mortality was plotted by using Prism 7 for Mac OS X ver. 7.0a (GraphPad Software, La Jolla, CA, USA).

\section{Results}

\subsection{Prevalence of the Disease across Acacia mangium Plantations}

Surveys conducted in the three $A$. mangium plantations and two trial plots revealed that the wilt disease occurred in the plantations only. The highest incidence was in Pahang plantations $(13.6 \%)$, followed by Johor plantations $(10.2 \%)$, while the lowest incidence was reported in Sarawak plantations (7.5\%) (Table 3). Singling through the removal of multiple stems from planted trees and animal damage were observed to be associated with Ceratocystis wilt disease only in the Sarawak plantations, with recorded incidence rates of $0.8 \%$ and $1.2 \%$, respectively.

Table 3. Prevalence of Ceratocystis wilt disease in five Acacia mangium plantations in Malaysia.

\begin{tabular}{ccccc}
\hline \multirow{2}{*}{ Plantation } & $\begin{array}{c}\text { No Sign or Symptom } \\
\text { Present (\%) }\end{array}$ & \multicolumn{2}{c}{$\begin{array}{c}\text { Insect } \\
(\mathbf{\%})\end{array}$} & $\begin{array}{c}\text { Incidence Rate * } \\
\text { (\%) }\end{array}$ \\
\cline { 3 - 5 } & & Asymptomatic & Symptomatic \\
\hline Johor & 71.2 & 18.6 & 10.2 & 10.2 \\
Sarawak & 86.2 & 6.3 & 5.5 & 7.5 \\
Pahang & 20.8 & 65.6 & 13.6 & 13.6 \\
\hline
\end{tabular}

* Incidence rate is based on the sum of symptomatic trees of insect and other contributing factors (animal damage \& pruning/singling).

In general, trees infected by the disease in the surveyed plantations occurred sporadically and individually. The infection symptoms varied from mild to severe. Some symptoms, such as bark depression, pale green, drying, and browning of phyllodes, wilting, and defoliation, were easily recognised. All the ten samples from suspected-infected trees from each plantation were examined and scrutinised for elliptical to longitudinal dark blue-black lesions, specifically on the wood underneath the bark. When the infected stems were cut transversely, blue-black streaks that penetrated the wood were observed. Small insect holes and gummosis were commonly found in the diseased trees. The white and odorous foam was visible on the stems and branches of a few trees. Nitidulid beetles and 
their larvae were often found aggregating near the foamy exudate. Nonetheless, root and root collar inspections of wilted trees did not necessarily show any disease symptoms.

\subsection{Insect Trapping, Incidence, and Identification}

Wood-boring insects were commonly present in infected trees, as seen in the plantations located in Pahang and Johor and compared to the plantations located in Sarawak. On average, each infested tree had around 10 to 20 insect holes on the stem. Trees without wilt disease symptoms but exhibiting signs of wood-boring insects were found in $18.6 \%, 6.3 \%$, and $65.6 \%$ of all the inspected trees in the states of Johor, Sarawak, and Pahang, respectively (Table 3). Three species of ambrosia beetles, namely, Xyleborus affinis, Hypothenemus sp., and Xylosandrus crassiusculus (Figure 1), were collected from the insect traps placed in the Pahang plantation. Xyleborus affinis was the most common species (with 15 individuals were trapped), as compared to Hypothenemus sp. (one individual was trapped) and X. crassiusculus (three individuals were trapped).
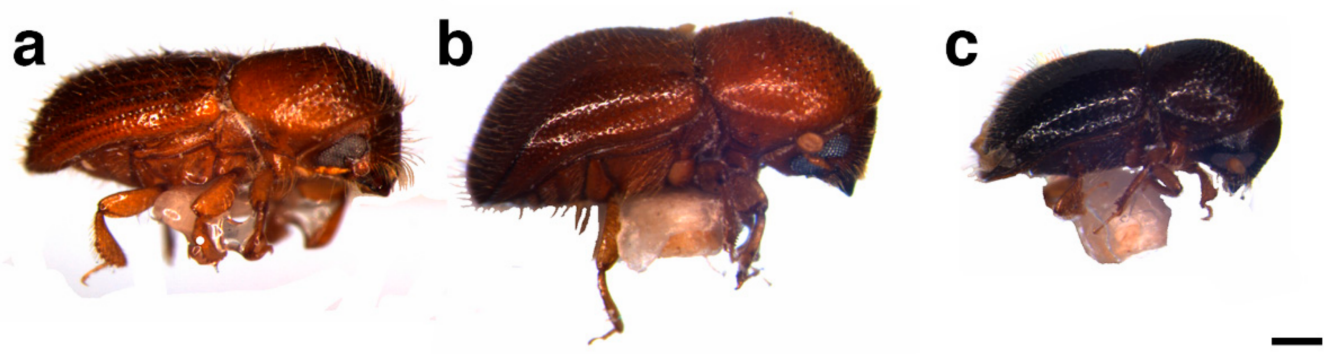

Figure 1. Collection of wood-boring insects from random insect traps in the Acacia mangium plantation in Pahang. (a) Xyleborus affinis, (b) Xylosandrus crassiusculus, and (c) Hypothenemus sp. [scale bar $=300 \mu \mathrm{m}$ ].

\subsection{Fungal Species Identification}

Sixteen fungal isolates derived from $A$. mangium trees with wilt disease symptoms were identified through cultural and morphological studies. All the isolates were identified based on the analyses of morphological characteristics, such as colony form, mycelium colour and reverse media colour (Figure 2) and were further identified as C. fimbriata. The cultures in PDA were cottony, sparse and were initially white but turned to olive-grey with white to grey at the margin after culturing for 5 to 7 days. The underside of the cultures was light grey at the margin and became darker towards the centre. In addition, the culture often produced a banana-like scent. Perithecia were common, and they mainly were superficial on the substrate. Ascospore masses attached to the apex of perithecia were present in abundance, and these masses changed from cream when young to orange when older. Long-necked perithecia, measuring from 133.2 to $281.5 \mu \mathrm{m}$ in length and between 128.2 to $283.0 \mu \mathrm{m}$ in width, were dark brown to black in colour and globose shaped (Figure 2a). Slender perithecial necks, measuring from around 282.7 to $776.3 \mu \mathrm{m}$ in length, 12.8 to $28.7 \mu \mathrm{m}$ wide at the tip, and 26.5 to $44.4 \mu \mathrm{m}$ at the base, were also similar in colour. Hyaline and aseptate ostiolar hyphae, ranging from 15.5 to $53.5 \mu \mathrm{m}$ in length, were diverse (Figure 2b). Meanwhile, hyaline ascospores were hat-shaped, with sizes ranging from 4.4-5.2 × 3.5-3.7 $\mu \mathrm{m}$ (Figure 2c).

The findings identified two types of conidia that were present in all the fungal isolates. The first type was cylindrical, while the second was shorter and more barrel-shaped (Figure 2d). The cylindrically shaped conidia were approximately $18.3-28.7 \times 4.2-4.5 \mu \mathrm{m}$, while the barrel-shaped conidia ranged from 8.6-12.7 $\times 4.2-4.6 \mu \mathrm{m}$. Both types of conidia were hyaline. Typically, aleuroconidia is arranged singly or basipetal in chains, thickwalled, pale brown to brown in colour, ovoid to obpyriform in shape, and has a smooth surface (Figure 2e). 


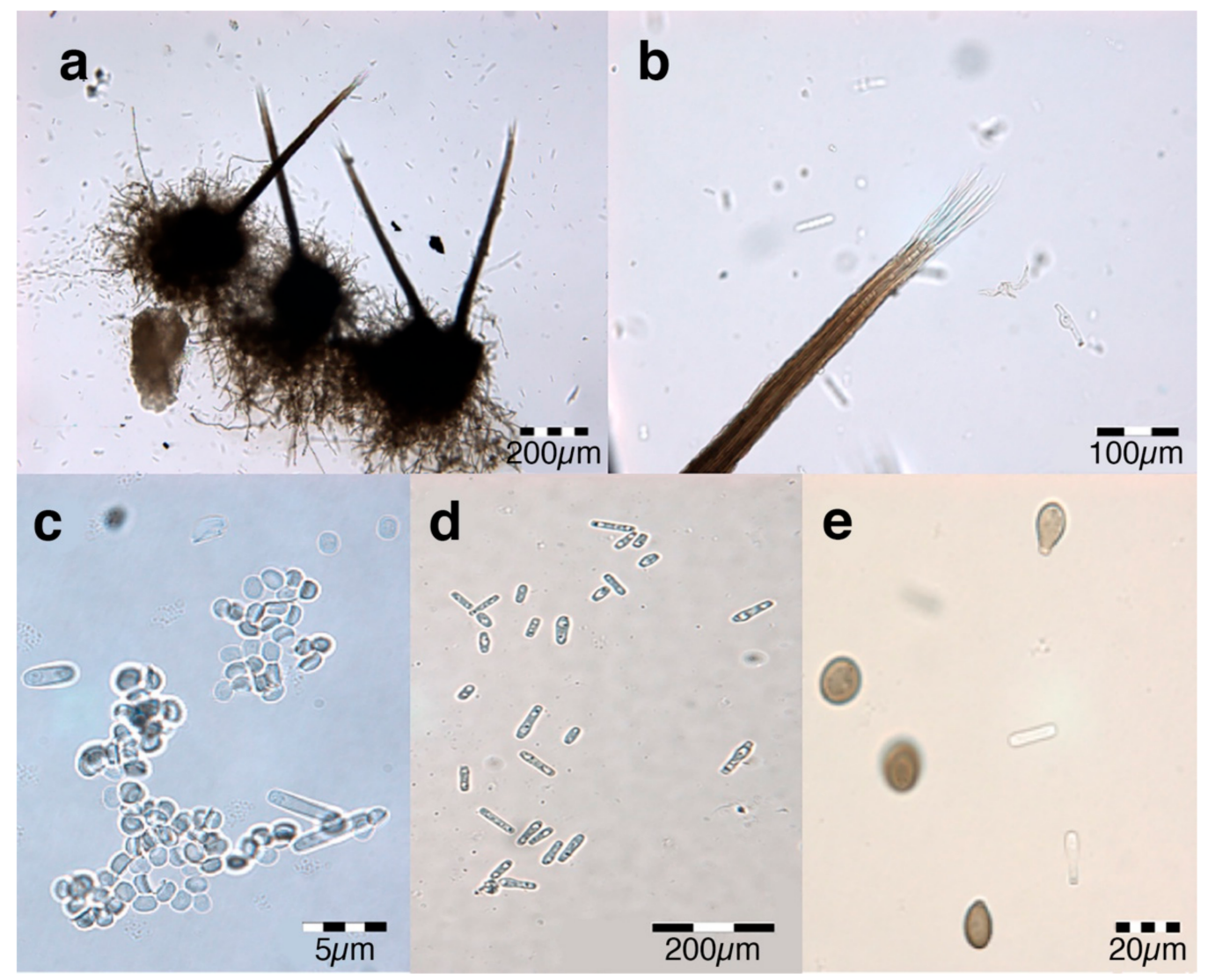

Figure 2. Ceratocystis fimbriata isolated from diseased Acacia mangium. (a) Dark brown long-necked perithecia. (b) Divergent ostiolar hyphae (c) Hat-shaped ascospores (d) Hyaline cylindrical and barrel-shaped conidia. (e) Brown and ovoid aleuroconidia.

\subsection{Multi Regions Phylogenetic Analysis}

The size estimation of the PCR amplified ITS, EF1 $\alpha$, and $\beta$ t regions were approximately 500 to $600 \mathrm{bp}, 670$ to $741 \mathrm{bp}$, and 490 to $600 \mathrm{bp}$, respectively. All the sequences were deposited into GenBank, with the accession numbers as presented in Table 1. Two phylogenetic analysis datasets, in addition to standalone ITS tree and unified EF1 $\alpha-\beta t$ tree, were prepared and aligned. The dataset consisted of 612 and 1444 characters, including alignment gaps for both the ITS and EF1 $\alpha-\beta$ t regions. ML and Bayesian analyses of both datasets culminated in the phylogenetic reconstruction of equivalent topologies (data not shown). The best ML trees were selected as the backbone tree, as shown in Figures 3 and 4 .

The phylogenetic tree from the ML and Bayesian analyses of ITS and EF1 $\alpha-\beta t$ data sets showed that all the Malaysian Ceratocystis isolates could be grouped with $C$. fimbriata sensu stricto (s.s.; Clade I). Clade I was formed by branching from Greece's C. platani with Venezuela's C. fimbriatomima, Columbia's C. papillata, Papua New Guinea's C. fimbriata, Brazil's Ceratocystis sp., and Oman's C. manginecans. Both trees are endorsed by 34/100 and 87/98 (ML/Bayesian) bootstrap values/percent probabilities for ITS and EF1 $\alpha-\beta \mathrm{t}$, respectively. The findings also revealed that the studied $C$. fimbriata isolates fell into subclade I and subclade II in the ITS tree, as endorsed by 83/99 and 13/99 bootstrap values/percent probabilities, respectively. Meanwhile, the outcome on the EF1 $\alpha$ - $\beta$ t tree was marginally different by shifts in the studied isolate representative on subclade II with $64 / 67$ bootstrap values/percent probabilities. 


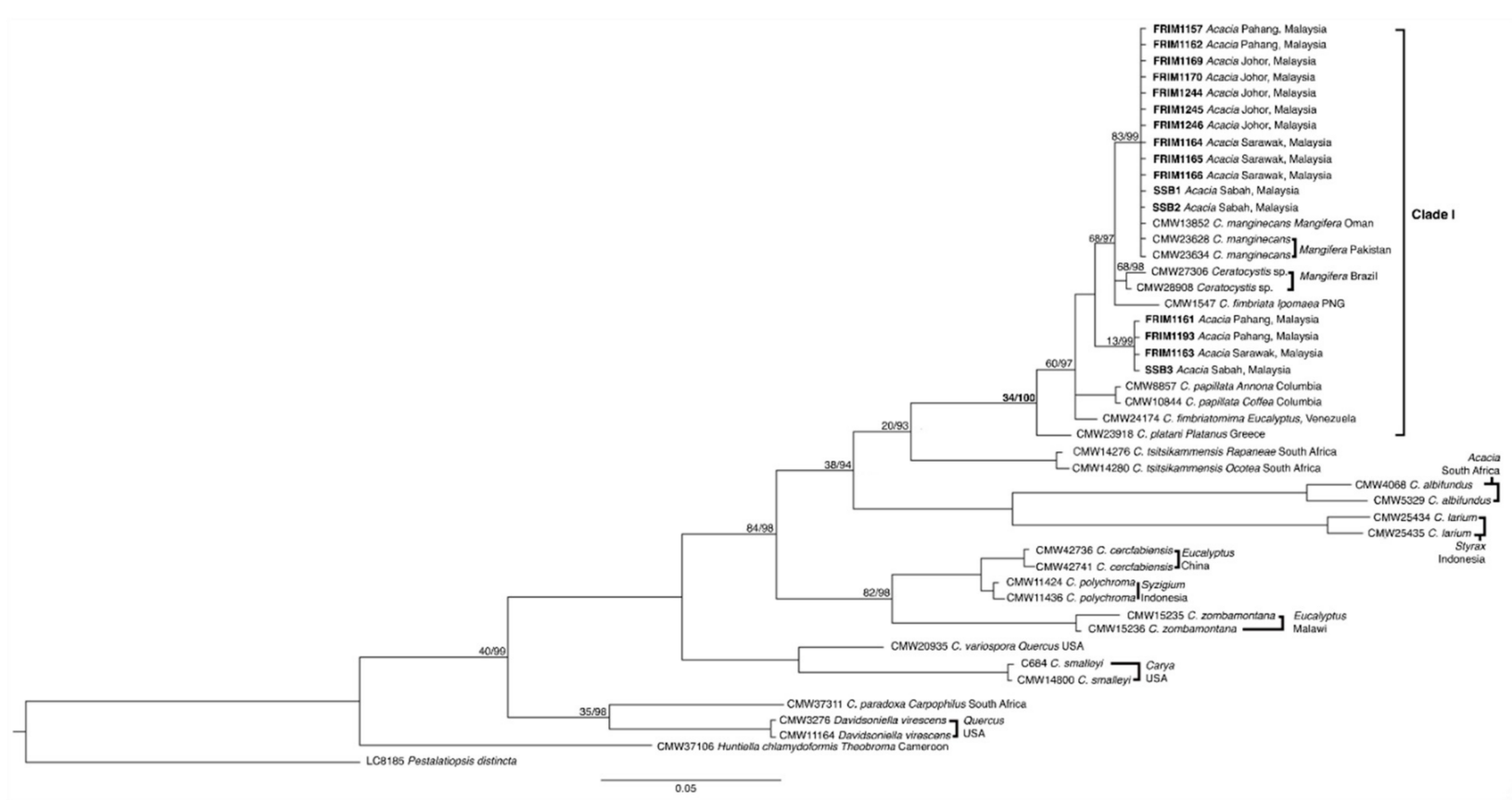

Figure 3. Maximum-likelihood (ML) analysis of Ceratocystis isolates from a dataset of ITS region sequence alignment. Branch support values on each node indicate the bootstrap values of ML and the percentage of Bayesian posterior probabilities. Highlighted isolates indicating Ceratocystis fimbriata from Acacia mangium host in Malaysia. Accession numbers of all sequences from isolated Ceratocystis fimbriata in this study and references are listed in Table 2.

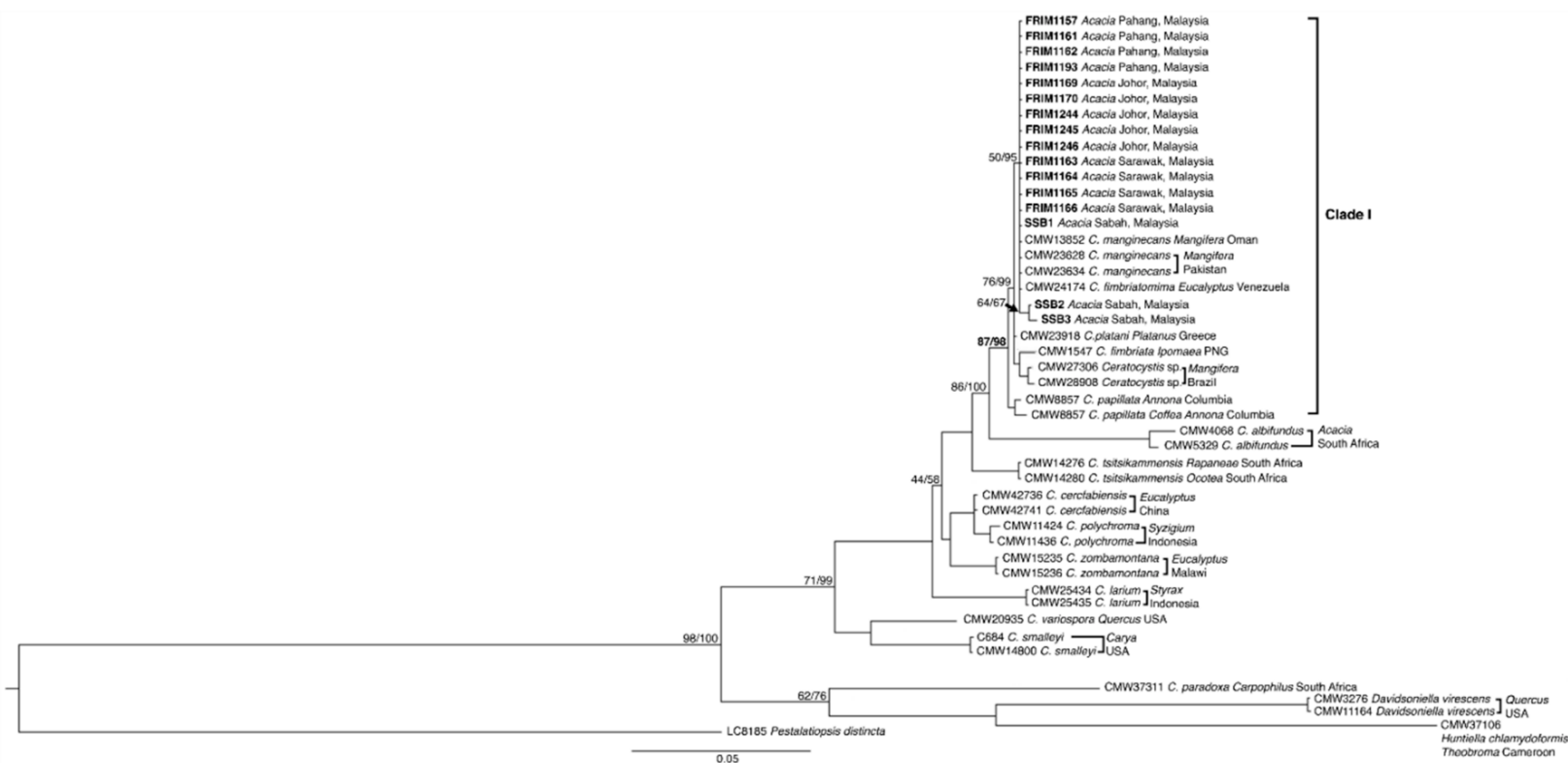

Figure 4. Maximum-likelihood (ML) analysis of Ceratocystis isolates from a dataset of EF1 $\alpha$ and $\beta$ T regions sequence alignment. Branch support values on each node indicates the bootstrap values of ML and the percentage of Bayesian posterior probabilities. Highlighted isolates indicating Ceratocystis fimbriata from Acacia mangium host in Malaysia.

\subsection{Pathogenicity Test}

In general, all the eight $C$. fimbriata species complex isolates used in the experiment were causing a pathogenic infection on A. mangium seedlings. Signs and symptoms of infections appeared one-week post-inoculation, similar to those observed in the field. Longitudinal stem discolouration and the presence of amber gummosis on the inoculated seedlings detected at the onset of inoculation were identified as early symptoms 
of $C$. fimbriata infection. More symptoms were detected over time, such as the manifestations of pale green foliage, wilting, defoliation and ultimately leading to the death of seedlings. Seedlings started to die as early as 14-days post-inoculation. Conversely, inoculated seedlings in the control group remained healthy and free of the disease symptoms, while the wounds healed by the end of the experiment.

The FRIM1162 isolate was confirmed as the most aggressive isolate against $A$. mangium seedlings. This isolated strain was obtained from a seven-year-old A. mangium tree in the Pahang plantation. The mean percentage of mortality after 35 days of inoculation with this fungal isolate was $60.42 \pm 4.84 \%$. Meanwhile, the second aggressive isolate was SSB3 that was isolated from Sabah (51.67 $\pm 4.04 \%)$. The least aggressive, SSB2 $(14.17 \pm 2.87 \%)$, was also isolated from Sabah. The analysis of variance (ANOVA) in the pathogenicity test $(\mathrm{F}=19.98$ at $p<0.05)$ also confirmed that all the fungal isolates differed significantly (Figure 5). Re-isolation of fungi strains from the diseased stems of all the inoculated seedlings successfully recovered the fungal pathogens. In contrast, none of the control seedlings yielded the fungal pathogens.

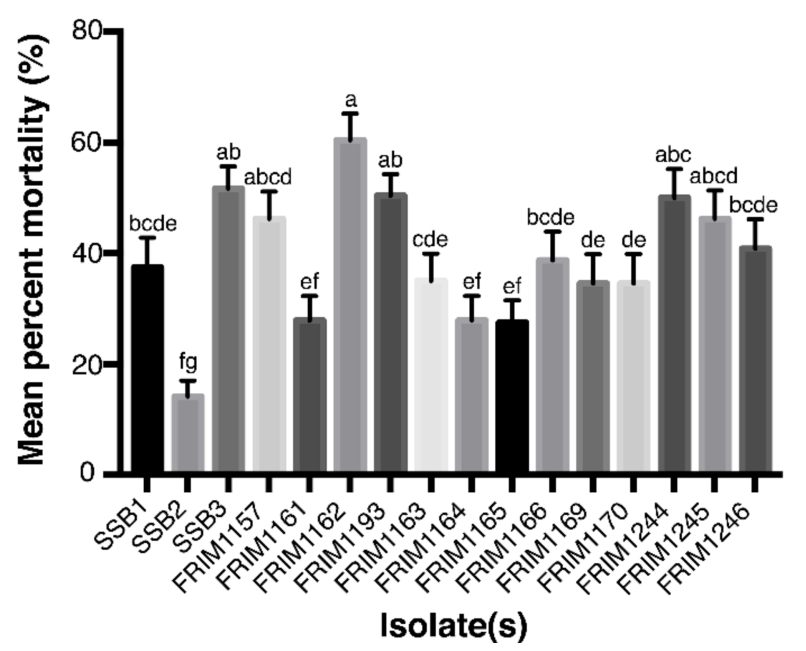

Figure 5. Mean mortality (in percentage) of Acacia mangium seedlings within 35 days post-inoculation with Ceratocystis fimbriata complex isolates obtained from selected Acacia mangium plantations in Malaysia. Means followed by the same letter are not significantly different at $p=0.05$ according to Tukey's test $=3.87$.

\subsection{Host Range Test against Ceratocystis fimbriata Isolates}

Most of the plant species used in the host range test survived the inoculations with C. fimbriata isolates, SSB3, and FRIM1162 for at least 35 days, except for the A. mangium species (SSB3: $\mathrm{F}=6.77$; FRIM1162: $\mathrm{F}=10.38, p<0.05$ ). All the A. malaccensis, $K$. ivorensis, and T. grandis seedlings inoculated with SSB3 and FRIM1162 remained healthy, as the seedlings did not exhibit any signs or symptoms of disease infection and survived until the end of the experimental period. More interestingly, the inoculation wounds performed previously on the seedlings had also healed completely. In contrast, all the inoculated A. mangium seedlings displayed symptoms of Ceratocystis wilt that are similar to those observed in the plantation. Re-isolation of fungus from the A. mangium seedlings successfully yielded C. fimbriata.

Meanwhile, $H$. brasiliensis and E. longifolia seedlings inoculated with both the fungal isolates showed some mortality signs by the end of the experiment. Physical examination of the dead seedlings revealed that the roots of the plants were rotted and creating a foul odour due to excessive watering. However, the re-isolation investigation failed to recover the inoculated Ceratocystis from any of the dead plants. 


\section{Discussion}

The results of this study showed that Ceratocystis wilt disease also occurs in A. mangium plantations in other Malaysian states, apart from Sabah. However, the prevalence of Ceratocystis wilt disease in the investigated plantations (Pahang (13.6\%), Johor (10.18\%), and Sarawak (7.53\%)) was still lower than in Sabah [9], Vietnam [7], and Indonesia [8]. This study revealed the first reported case of Ceratocystis wilt in the assessed plantations. The incidences may arise in subsequent rotations as well. Additionally, the majority of the plantation did not conduct any silviculture practises, including pruning and singling.

It has been established that Ceratocystis is known as a wound-infecting pathogen pp. 173-183 in [20]. Wilt disease caused by pruning and animal damage wounds is uncommon and is only reported in Sarawak. Numerous infections, including Ceratocystis, may infect pruning and singling wounds $[5,57,58]$. In this study, no trees were found to have infected the root from $C$. fimbriata's soil-borne inoculum. The amount of $C$. fimbriata inoculum source present in the topsoil of each plantation surveyed may be limited due to the second planting rotation. Future research on Ceratocystis inoculum sources in topsoil should be considered.

In Sabah, silviculture practises such as pruning, and singling were linked to increased wilt disease incidence [9]. These practices also killed $50 \%$ of $1500 \mathrm{~A}$. mangium trees in a 2-year-old plantation in Johor [59]. In the plantations surveyed in this study, a few trees were singled due to the presence of co-dominant leaders, which could have resulted in the low incidence of wilt disease. The occurrence of wilt disease due to wounds created by bark peeling has been reported in A. mangium plantations in Sumatra and Sabah [4]. Apart from squirrels, elephants, wild boars, deer, and monkeys cause tree bark damage in Pahang and Johor.

These wounds may help in the disease spreading by recruiting nitidulid beetles that transmit Ceratocystis spp. [60,61]. However, researchers in Indonesia, Malaysia, and Vietnam have yet to confirm this hypothesis for A. mangium wilt. The speculation was based on reports of oak wilt disease in the United States where fungal species were often isolated from the nitidulid beetles; Colopterus truncates, Co. semitectus and Co. niger were found to be vectors of Bretziella fagacearum, Ophiostoma piceae, and O. pluriannulata [60,62]. More studies are needed to determine the nitidulid beetles that cause A. mangium wilt in Malaysia and transmit C. fimbriata. However, pathogens have been reported to be transported by wind, particularly in ambrosia beetle frass [63], though this has yet to be investigated in Malaysia.

Infestation of $A$. mangium stems by wood-boring insects were prevalent in the examined plantations. However, many of these trees, particularly in Pahang and Johor, remained undamaged and were free of disease symptoms. Most of the insect holes were superficial, clean, and did not show any signs of the disease. Ceratocystis was found in a few trees with insect damage, where the holes were commonly accompanied by dark gummosis and liquid oozing. Gummosis, or polysaccharide gel formation, is a typical tree reaction to pathogen infection, insect attack, and wounding [64].

The role of the ambrosia beetle, X. affinis as a disease-transmitting agent for Ceratocystis is still unclear. Ceratocystis was not successfully isolated from the plantations' insects, indicating that they did not vector the fungus. Therefore, we presume the wood-boring insects found in Pahang and Johor are a secondary infestation caused by abiotic tree stress. The A. mangium trees in these plantations have smaller diameter stems and sparser canopies than those in Sarawak. Trees in Pahang and Johor plantations thus displayed indicators often associated with tree stress [65]. Unlike other ambrosia beetles such as X. glabratus, which is a vector for Raffaelea lauricola [66], healthy standing trees are rarely infested by $X$. affinis [67].

No fungi, including Ceratocystis, were found on all the any insect-damaged trees assessed in this investigation. The lack of Ceratocystis fungi on the insect bodies may have been contributed by the failure of isolation. It is hard to ascertain whether the disease is spread by insect vectors unless more thorough investigations are being conducted. The advanced technique should be used to confirm Ceratocystis availability on suspected insect 
vectors. Ceratocystis propagules were found on the related ambrosia beetle genus, Xyleborus [68]. According to Roy et al. [69], Xyleborus affinis is one of the ambrosia beetle species found to be a suspected spreading vector for Ceratocystis lukuohia on Metrosideros polymorpha host in Hawai'i. Propagules of C. lukuohia were also found on X. simillimus [68,69]. A bark beetle, Hypocryphalus mangiferae, was described as a vector for C. manginecans in Pakistan, Brazil, and Oman $[66,70,71]$. Platypus cylindrus, an ambrosia beetle, was reported to be a vector of C. platani in Platanus orientalis plantations in Greece [72]. However, these vectors were not discovered in the insect traps set up in the plantations. Based on our findings, more researches into insect vectors in plantations are needed. The results of this study can also assess the diversity and richness of wood-boring insects in plantations. More traps should be set up, while regular sampling should be conducted by considering the meteorological conditions, temperature, rainfall, and humidity.

Borneo Island isolates were morphologically identical to Peninsula isolates. The sizes of the perithecia, ascospores, cylindrical and barrel-shaped conidia were varied with the reported sizes but were still within the species' range. All the fungal isolates from Peninsular Malaysia and Borneo Island met the description of C. fimbriata CBS 114,723 epitype strains isolated from sweet potato in North Carolina, USA, as reported previously by Marincowitz et al. [30]. The sizes of these fungal structures varied amongst $C$. fimbriat $a$ isolates from different sites and hosts [29]. Although the morphology of C. fimbriata and C. manginecans is similar, the molecular approaches employed for fungal identification instead showed that these two species are not the same [73]. Our phylogenetic analysis confirmed the morphological identification. This clade includes $C$. manginecans from Oman and Pakistan, Ceratocystis fimbriata from Papua New Guinea and Ceratocystis sp. from Brazil. Ceratocystis manginecans share the same space with $C$. fimbriata, and this finding is not surprising due to their origins and host plants. Poussio et al. [14] described C. fimbriata as a complex species. The ITS tree could not discriminate the $C$. fimbriata strains tested in this investigation because haploid genomes contain several ITS sequences; therefore the ITS region is not optimal for species delimitation [74,75]. The latest study's EF1 $\alpha-\beta T$ tree had a better resolution of $C$. fimbriata phylogeny. The EF1 $\alpha-\beta T$ tree showed that the $C$. fimbriata isolates are clustering with $C$. platani and $C$. apillate. In the recent molecular analyses, these Ceratocystis strains have been placed into the $C$. fimbriata of Brazilian populations [11,12]. Thus, the results validated and supported that this currently studied Ceratocystis isolates are $C$. fimbriata complex.

It was determined that $C$. fimbriata complex caused wilt disease in the Malaysian A. mangium plantations based on the pathogenicity test conducted. The pathogenicity of isolates from different $A$. mangium plantations in Sabah ranged from weak to highly aggressive. These variations suggested that $C$. fimbriata aggression is unrelated to the geographical origins. Therefore, the current result supported previous pathogenicity investigations on the pathogen from numerous Brazilian states [76,77]. The Pahang isolate (FRIM 1162) was determined to be the most aggressive in destroying seedlings. This isolate, along with a low aggressive isolate, can be employed in screening programmes to breed A. mangium with resistance to Ceratocystis wilt $[76,78]$. The aggression heterogeneity of fungal isolates is crucial for developing efficient disease control approaches. These isolates could be used in the laboratory to assess fungicides and host ranges, thus providing significant and reliable baseline results to compare the pathogenicity levels of unknown wild strains.

The host range study revealed that A. maleccensis, E. longifolia, H. brasilensis, K. ivorensis, and $T$. grandis might be a non-host plant to $C$. fimbriata infection. A comparable investigation performed previously in Brazil demonstrated that the fungus was not harmful to H. brasiliensis and T. grandis [76]. More interestingly, the inoculated wound often recovered. The present investigation did not find any mouldy rot or grey mould on the inoculated $H$. brasiliensis seedlings, similar to the findings reported in the Brazilian study [76,79]. As per our knowledge, this is the first time A. maleccansis, K. ivorensis, and E. longifolia were tested as potential pathogenicity hosts of $C$. fimbriata, and the results showed that 
all the inoculated plant species survived until the end of the experiment. These findings may imply that the pathogen specificity for A. mangium was relative to other test hosts. The results of this study confirmed the low infectious risk of Ceratocystis wilt disease in Malaysian A. malaccensis, E. longifolia, H. brasilensis, K. ivorensis, and T. grandis plantations. This information is vital because forest species, particularly rubber and A. malaccensis, are important economic contributors to Malaysia. Information from this study also benefits the planters who plant E. longifolia and A. mangium with the agroforestry concept.

Although the occurrence of the wilt disease was relatively low, it could still spread and kill significant areas of $A$. mangium plantations if the pest and disease management techniques are not being regulated. Hence, regular monitoring is required to prevent disease transmission. Moreover, the role of insect vectors in transmitting Ceratocystis wilt disease in the plantations remains uncertain, so more investigations are needed to identify the role of wood-boring insects in circulating the infection in plantations. Even though pruning/singling wounds and animal damage are detected in affected plants, more data are required to ascertain their effects on accelerating the fungal infection.

\section{Conclusions}

Based on the morphological characteristics and identification of DNA sequences, this study found that $C$. fimbriata complex is a causal organism of wilt disease that leads to significant severity of infection in A. mangium plantations in Malaysia. The $C$. fimbriata samples were isolated from the infected stems of plants in different $A$. mangium plantations were also proven to cause mortality based on the pathogenicity test that was carried out on the inoculated trees planted in the nursery. Meanwhile, the host range test showed that selected local forest plantation species were not susceptible and may be resistant to the inoculated C. fimbriata. Therefore, this information might give early insight into the disease occurrence of this ferocious plant pathogen. Furthermore, the knowledge can serve as a precautionary measure for the forest plantation stakeholders in the future.

Author Contributions: Conceptualization, S.A.S., A.M.-F., and R.M.; methodology, S.A.S., A.M.-F., R.M., S.P.O., and H.M.S.; software, S.A.S., W.-A.W.-M.-A., and H.M.S.; validation, A.M.-F., R.M., and A.M.Z.; formal analysis, S.A.S., W.-A.W.-M.-A., and S.P.O.; investigation, S.A.S., W.-A.W.-M.-A., and S.P.O.; resources, A.M.-F.; data curation, S.A.S. and A.M.-F.; writing-original draft preparation, S.A.S.; writing — review and editing, A.M.-F., H.M.S., and R.M.; visualization, S.A.S.; supervision, A.M.-F. and R.M.; project administration, A.M.-F.; funding acquisition, A.M.-F. All authors have read and agreed to the published version of the manuscript.

Funding: This research was funded by Ministry of Energy and Natural Resources of Malaysia, (Additional 10th Malaysia Plan Project Grant. Grant number: P23 085100010021 and 12th Malaysia Plan Project Grant. Grant number: FRIM(S).600-3/1/18).

Data Availability Statement: I The DNA sequences generated and analysed in this paper are available in GenBank (https:/ / www.ncbi.nlm.nih.gov/genbank/, accession numbers listed in the Table 1, last accessed on 21 June 2021) The DNA sequences were submitted on 11 June 2018 (Accession number: MF522233-MF522249) and 28 Jan 2020 (MN296219-MN296250).

Acknowledgments: We acknowledge the director general of Forest Research Institute Malaysia and the director of the Forest Biodiversity Division for their continuous support. The assistance rendered from members of the Mycology and Pathology Laboratory (Anida, Atikah, Fakhruddin, Fariza, Jamaluddin, Kamarul, and Salleh) and Sarawak Forestry Department (Annya, Hamzah, Kamal, Lelawati, Marfaizal, Princilla) throughout this research, especially the surveys and collection of diseased samples are highly appreciated. The authors also thanks Yani Japarudin of the Sabah Softwood Ltd. for contributing the Ceratocystis isolates.

Conflicts of Interest: The authors declare no conflict of interest. 


\section{References}

1. Sarawak Moving towards Pulp, Paper Industries. Available online: https://www.theborneopost.com/2012/11/28/swakmoving-towards-pulp-paper-industries / (accessed on 9 May 2021).

2. Forestry Department Peninsular Malaysia. Annual Report 2011; Ministry of Energy and Natural Resources: Kuala Lumpur, Malaysia, 2012; p. 192.

3. Hashim, M.N.; Mohd-Hazim, M.A.; Syafinie, A.M. Strategic Forest plantation establishment in Malaysia for future product development and utilization. In Proceedings of the Kuala Lumpur International Agriculture, Forestry and Plantation, Kuala Lumpur, Malaysia, 12-13 September 2015; pp. 1-16.

4. Harwood, C.E.; Nambiar, E.K.S. Sustainable plantation forestry in South-East Asia. In Australian Centre for International Agricultural Research (Ed.), ACIAR Technical Reports No. 84; Australian Centre for International Agricultural Research: Canberra, Australia, 2014; p. 100.

5. Tarigan, M.; Roux, J.; van Wyk, M.; Tjahjono, B.; Wingfield, M.J. A new wilt and die-back disease of Acacia mangium associated with Ceratocystis manginecans and C. acaciivora sp. nov. in Indonesia. S. Afr. J. Bot. 2011, 77, 292-304. [CrossRef]

6. Hardiyanto, E. Operational challenges in managing productivity in multispecies plantations [abstract]. In Promoting Sustainable Resources from Plantations for Economic Growth and Community Benefits; IUFRO-INAFOR Joint International Conference: Yogjakarta, Indonesia, 2017; pp. 24-27.

7. Thu, P.Q.; Quynh, D.N.; Fourie, A.; Barnes, I.; Wingfield, M.J. Ceratocystis wilta serious threat to Acacia plantations in Vietnam. In Proceedings of the Workshop Ceratocystis in Tropical Hardwood Plantations, Yogyakarta-Riau, Indonesia, 15-18 February 2016; p. 35.

8. Brawner, J.; Japarudin, Y.; Lapammu, M.; Rauf, R.; Boden, D.; Wingfield, M.J. Evaluating the inheritance of Ceratocystis acaciivora symptom expression in a diverse Acacia mangium breeding population. South. For. J. For. Sci. 2015, 77, 83-90. [CrossRef]

9. Maid, M.; Wickneswari, R. Incidences and severity of vascular wilt in Acacia mangium plantations in Sabah, Malaysia. In Proceedings of the the 2014 UKM FST Postgraduate Colloquium, Selangor, Malaysia, 9-11 April 2014; pp. 784-789. [CrossRef]

10. Tarigan, M.; van Wyk, M.; Roux, J.; Tjahjono, B.; Wingfield, M.J. Three new Ceratocystis spp. in the Ceratocystis moniliformis complex from wounds on Acacia mangium and A. crassicarpa. Mycoscience 2010, 51, 53-67. [CrossRef]

11. Fourie, A.; Wingfield, M.J.; Wingfield, B.D.; Thu, P.Q.; Barnes, I. A possible centre of diversity in Southeast Asia for the tree pathogen, Ceratocystis manginecans. Infect. Genet. Evol. 2016, 41, 73-83. [CrossRef] [PubMed]

12. Oliveira, L.S.S.; Harrington, T.C.; Ferreira, M.A.; Damacena, M.B.; Al-Sadi, A.M.; Al Mahmooli, H.I.S.; Alfenas, A.C. Species or genotypes? Reassessment of four recently described species of the Ceratocystis wilt pathogen, C. fimbriata, on Mangifera indica. Phytopathology 2015, 105, 1229-1244. [CrossRef]

13. Viégas, A.P. Mango blight. Bragantia 1960, 19, 162-182. [CrossRef]

14. Poussio, G.B.; Kazmi, M.R.; Akem, C.; Fateh, F.S. First record of Ceratocystis fimbriata associated with shisham (Dalbergia sissoo) decline in Pakistan. Australas. Plant Dis. Notes 2010, 5, 63-65. [CrossRef]

15. van Wyk, M.; Al-Adawi, A.O.; Khan, I.A.; Deadman, M.L.; Al-Jahwari, A.A.; Wingfield, B.D.; Wingfield, M.J. Ceratocystis manginecans sp. nov., causal agent of a destructive mango wilt disease in Oman and Pakistan. Fungal Div. 2007, 27, 213-230.

16. Somasekhara, Y.M. New record of Ceratocystis fimbriata causing wilt of pomegranate in India. Plant Dis. 1999, 83, 400. [CrossRef]

17. Baker, C.J.; Harrington, T.C.; Krauss UAlfenas, A.C. Genetic variability and host specialization in the Latin American clade of Ceratocystis fimbriata. Phytopathology 2003, 93, 1274-1284. [CrossRef] [PubMed]

18. Silveira, A.P.; Oliveira, D.A.; Cardoso, R.M.G.; Neto, F.B.; Ortolani, A.A.; Godoy, G.J. Characterization of mouldy rot (Ceratocystis fimbriata) damage on the rubber tree (Hevea brasiliensis) crop panel. Summa Phytopathol. 1994, 20, 196-199.

19. Teviotdale, B.L.; Harper, D.H. Infection of pruning and small bark wounds in almond by Ceratocystis fimbriata. Plant Dis. 1991, 75, 1026-1030. [CrossRef]

20. Wingfield, M.J.; Seifert, K.A.; Webber, J.F. Ceratocystis and Ophiostoma: Taxonomy, Ecology and Pathogenicity; APS Press: Eagan, MN, USA, 1993.

21. Nasution, A.; Glen, M.; Beadle, C.; Mohammed, C. Ceratocystis wilt and canker-A disease that compromises the growing of commercial Acacia-based plantations in the tropics. Aust. For. 2019, 82, 80-93. [CrossRef]

22. Rossetto, C.J.; Ribeiro, I.J.A. Mango wilt. XII. Recommendations for control. Rev. Agric. 1990, 65, $173-180$.

23. Marin, M.; Castro, B.; Gaitan, A.; Preisig, O.; Wingfield, B.D.; Wingfield, M.J. Relationships of Ceratocystis fimbriata isolates from Colombian coffee-growing regions based on molecular data and pathogenicity. J. Phytopathol. 2003, 151, 395-405. [CrossRef]

24. Iton, E.F. Studies on a wilt disease of cacao at River Estate. II. Some aspects of wind transmission. In Imperial College of Tropical Agriculture (Ed.), Annual Report on Cacao Research 1959-1960; University of The West Indies: St. Augustine, Trinidad \& Tobago, 1960; pp. 47-58.

25. Lindgren, B.S. A multiple funnel trap for scolytid beetles (Coleoptera). Can. Entomol. 1983, 115, 299-302. [CrossRef]

26. Reding, M.E.; Schultz, P.B.; Ranger, C.M.; Oliver, J.B. Optimizing ethanol-baited traps for monitoring damaging ambrosia beetles (Coleoptera: Curculionidae, Scolytinae) in ornamental nurseries. J. Econ. Entomol. 2011, 104, 2017-2024. [CrossRef] [PubMed]

27. Moller, W.J.; De Vay, J.E. Carrot as a species-selective isolation medium for Ceratocystis fimbriata. Phytopathology 1968, 58, $123-124$.

28. Von Arx, J.A. The Genera of Fungi Sporulating in Pure Culture; Lubrecht \& Cramer Ltd: Berlin, Germany, 1970 ; p. 288.

29. Engelbrecht, C.J.; Harrington, T.C. Intersterility, morphology and taxonomy of Ceratocystis fimbriata on sweet potato, cacao, and sycamore. Mycologia 2005, 97, 57-69. [CrossRef] [PubMed] 
30. Marincowitz, S.; Barnes, I.; De Beer, Z.W.; Wingfield, M.J. Epitypification of Ceratocystis fimbriata. Fungal Syst. Evol. $2020,6,289$. [CrossRef] [PubMed]

31. Zhang, K.; Yuan-Ying, S.; Cai, L. An optimized protocol of single spore isolation for fungi. Cryptogam. Mycol. 2013, 34, 349-356. [CrossRef]

32. White, T.J.; Bruns, T.D.; Lee, S.; Taylor, J.W. Amplification, and direct sequencing of fungal ribosomal RNA genes for phylogenetics. In PCR Protocols: A Guide to Methods and Applications; Innis, M.A., Gelfand, D.H., Sninsky, J.J., White, T.J., Eds.; Acad Press: New York, NY, USA, 1990; pp. 315-322.

33. Jacobs, K.; Bergdahl, D.R.; Wingfield, M.J.; Halik, S.; Seifert, K.A.; Bright, D.E.; Wingfield, B.D. Leptographiu wingfieldii introduced into North America and found associated with exotic Tomicus piniperda and native bark beetles. Mycol. Res. 2004, 108, 411-418. [CrossRef] [PubMed]

34. Glass, N.L.; Donaldson, G.C. Development of primer sets designed for use with the PCR to amplify conserved genes from filamentous ascomycetes. Appl. Environ. Microbiol. 1995, 61, 1323-1330. [CrossRef]

35. Harrington, T.C.; Thorpe, D.J.; Alfenas, A.C. Genetic variation and variation in aggressiveness to native and exotic hosts among Brazilian populations of Ceratocystis fimbriata. Phytopathology 2011, 101, 555-566. [CrossRef]

36. Rehner, S.A.; Buckley, E. A Beauveria phylogeny inferred from nuclear ITS and EF1- $\alpha$ sequences: Evidence for cryptic diversification and links to Cordyceps teleomorphs. Mycologia 2005, 97, 84-98. [CrossRef] [PubMed]

37. Mbenoun, M.; Wingfield, M.J.; Boyogueno, A.D.B.; Wingfield, B.D.; Roux, J. Molecular phylogenetic analyses reveal three new Ceratocystis species and provide evidence for geographic differentiation of the genus in Africa. Mycol. Prog. 2014, 13, 219-240. [CrossRef]

38. Edgar, R.C. MUSCLE: Multiple sequence alignment with high accuracy and high throughput. Nucleic Acids Res. 2004, 32, 1792-1797. [CrossRef]

39. Villesen, P. FaBox: An online toolbox for fasta sequences. Mol. Ecol. Notes 2007, 7, 965-968. [CrossRef]

40. Swofford, D.L.; Sullivan, J. Phylogeny inference based on parsimony and other methods using PAUP. In The Phylogenetic Handbook: A Practical Approach to DNA and Protein Phylogeny; Salemi, M., Vandamme, A., Eds.; Cambridge Univ Press: Cambridge, UK, 2003; pp. 267-312.

41. Guindon, S.; Dufayard, J.F.; Lefort, V.; Anisimova, M.; Hordijk, W.; Gascuel, O. New algorithms and methods to estimate maximum-likelihood phylogenies: Assessing the performance of PhyML 3.0. Syst. Biol. 2010, 59, 307-321. [CrossRef] [PubMed]

42. Darriba, D.; Taboada, G.L.; Doallo, R.; Posada, D. jModelTest 2: More models, new heuristics and parallel computing. Nat. Method. 2012, 9, 772. [CrossRef]

43. Hasegawa, M.; Kishino, H.; Yano, T.A. Dating of the human-ape splitting by a molecular clock of mitochondrial DNA. J. Mol. Evol. 1985, 22, 160-174. [CrossRef] [PubMed]

44. Ronquist, F.; Teslenko, M.; Van Der Mark, P.; Ayres, D.L.; Darling, A.; Höhna, S.; Larget, B.; Liu, L.; Suchard, M.A.; Huelsenbeck, J.P. MrBayes 3.2: Efficient Bayesian phylogenetic inference and model choice across a large model space. Syst. Biol. 2012, 61, 539-542. [CrossRef] [PubMed]

45. Han, M.V.; Zmasek, C.M. phyloXML: XML for evolutionary biology and comparative genomics. BMC Bioinform. 2009, 10, 356. [CrossRef] [PubMed]

46. van Wyk, M.; van der Merwe, N.A.; Roux, J.; Wingfield, B.D.; Kamgan, G.N.; Wingfield, M.J. Population genetic analyses suggest that the Eucalyptus fungal pathogen Ceratocystis fimbriata has been introduced into South Africa. S. Afr. J. Sci. 2006, 102, 259-263. [CrossRef]

47. Liu, F.F.; Barnes, I.; Roux, J.; Wingfield, M.J.; Chen, S. Molecular phylogenetics and microsatellite analysis reveal a new pathogenic Ceratocystis species in the Asian-Australian clade. Plant Pathol. 2018, 67, 1097-1113. [CrossRef]

48. Barnes, I.; Gaur, A.; Burgess, T.; Roux, J.; Wingfield, B.D.; Wingfield, M.J. Microsatellite markers reflect intra-specific relationships between isolates of the vascular wilt pathogen Ceratocystis fimbriata. Mol. Plant Pathol. 2001, 2, 319-325. [CrossRef] [PubMed]

49. van Wyk, M.; Wingfield, B.D.; Marin, M.; Wingfield, M.J. New Ceratocystis species infecting coffee, cacao, citrus and native trees in Colombia. Fungal Divers. 2010, 40, 103-117. [CrossRef]

50. van Wyk, M.; Al-Adawi, A.O.; Wingfield, B.D.; Al-Subhi, A.M.; Deadman, M.L.; Wingfield, M.J. DNA based characterization of Ceratocystis fimbriata isolates associated with mango decline in Oman. Austral. Plant Pathol. 2005, 34, 587-590. [CrossRef]

51. van Wyk, M.; Wingfield, B.D.; Al-Adawi, A.O.; Rossetto, C.J.; Ito, M.F.; Wingfield, M.J. Two new Ceratocystis species associated with mango disease in Brazil. Mycotaxon 2011, 117, 381-404. [CrossRef]

52. van Wyk, M.; Wingfield, B.D.; Clegg, P.A.; Wingfield, M.J. Ceratocystis larium sp. nov., a new species from Styrax benzoin wounds associated with incense harvesting in Indonesia. Persoonia 2009, 22, 75. [CrossRef] [PubMed]

53. Van Wyk, M.; Pegg, G.; Lawson, S.; Wingfield, M.J. Ceratocystis atrox sp. nov. associated with Phoracantha acanthocera infestations on Eucalyptus grandis in Australia. Austral. Plant Pathol. 2007, 36, 407-414. [CrossRef]

54. Holland, L.A.; Lawrence, D.P.; Nouri, M.T.; Travadon, R.; Harrington, T.C.; Trouillas, F.P. Taxonomic revision and multi-locus phylogeny of the North American clade of Ceratocystis. Fungal Syst. Evol. 2019, 3, 135. [CrossRef] [PubMed]

55. Kamgan, N.G.; Jacobs, K.; De Beer, Z.W.; Wingfield, M.J.; Roux, J. Ceratocystis and Ophiostoma species including three new taxa, associated with wounds on native South African trees. Fungal Divers. 2008, 29, 37-59.

56. Heath, R.N.; Wingfield, M.J.; Wingfield, B.D.; Meke, G.; Mbaga, A.; Roux, J. Ceratocystis species on Acacia mearnsii and Eucalyptus spp. in eastern and southern Africa including six new species. Fungal Divers. 2009, 34, 41-67. 
57. Glass, B.P.; McKenzie, H. Decay distribution in relation to pruning and growth stress in plantation-grown Eucalyptus regnans in New Zealand. N. Z. J. For. Sci. 1989, 19, 210-222.

58. Vartiamäki, H.; Hantula, J.; Uotila, A. Susceptibility of silver birch pruning wounds to infection by white-rot fungus (Chondrostereum purpureum), a potential bioherbicide. Silva. Fenn. 2009, 43, 537-547. [CrossRef]

59. Mohd-Farid, A.; Syazwan, S.A.; Wan-Muhd-Azrul, W.A.; Patahayah, M.; Mohd-Salleh, S.; Ong, S.P. Ceratocystis fimbriata: A white listed alien invasive species (AIS) causing wilt disease on Acacia mangium plantation. FRIM Tech. Inf. 2018, 83, 1-6.

60. Appel, D.N.; Kurdyl, T.; Lewis, J.r.R. Nitidulids as vectors of the oak wilt fungus and other Ceratocystis spp in Texas. Eur. J. For. Pathol. 1990, 20, 412-417. [CrossRef]

61. Hayslett, M.; Juzwik, J.; Camilli, K.; Appel, D. Frequencies of Ceratocystis fagacearum contaminated nitidulid beetle species in wounds on live and red oaks in Texas. Phytopathology 2005, 95, S41.

62. De Beer, Z.W.; Marincowitz, S.; Duong, T.A.; Wingfield, M.J. Bretziella, a new genus to accommodate the oak wilt fungus, Ceratocystis fagacearum (Microascales, Ascomycota). MycoKeys 2017, 27, 1-19. [CrossRef]

63. Engelbrecht, C.J.; Harrington, T.C.; Alfenas, A.C.; Suarez, C. Genetic variation in populations of the cacao wilt pathogen, Ceratocystis cacaofunesta. Plant Pathol. 2007, 56, 923-933. [CrossRef]

64. Boothby, D. Gummosis of stone-fruit trees and their fruits. J. Sci. Food Agric. 1983, 34, 1-7. [CrossRef]

65. Lily, S.J. Arborists' Certification Study Guide; International Society of Arboriculture: Savoy, IL, USA, 2010; p. 352.

66. Ploetz, R.C.; Hulcr, J.; Wingfield, M.J.; de Beer, Z.W. Destructive tree diseases associated with ambrosia and bark beetles: Black swan events in tree pathology? Plant Dis. 2013, 97, 856-872. [CrossRef] [PubMed]

67. Bright, D.E. Review of the tribe Xyleborini in America north of Mexico (Coleoptera: Scolytidae). Can. Entomol. 1968, 100, 1288-1323. [CrossRef]

68. Roy, K.; Ewing, C.P.; Hughes, M.A.; Keith, L.; Bennett, G.M. Presence and viability of Ceratocystis lukuohia in Ambrosia beetle frass from Rapid 'Ōhi'a death-affected Metrosideros polymorpha trees on Hawai'i Island. For. Pathol. 2019, 49, e12476. [CrossRef]

69. Roy, K.; Jaenecke, K.A.; Peck, R.W. Ambrosia beetle (Coleoptera: Curculionidae) communities and frass production in 'Ōhi'a (Myrtales: Myrtaceae) infected with Ceratocystis (Microascales: Ceratocystidaceae) fungi responsible for rapid 'Ōhi'a death. Environ. Entomol. 2020, 49, 1345-1354. [CrossRef] [PubMed]

70. Masood, A.; Stoeckle, B.C.; Kuehn, R.; Shafqat, S. Cross species transfer of microsatellite loci in Scolytidae species mostly associated with mango (Mangifera indica L., Anacardiaceae) quick decline disease. Pak. J. Zool. 2011, 43, 411-414.

71. Al-Adawi, A.O.; Al-Jabri, R.M.; Deadman, M.L.; Barnes, I.; Wingfield, B.D.; Wingfield, M.J. The mango sudden decline pathogen, Ceratocystis manginecans, is vectored by Hypocryphalus mangiferae (Coleoptera: Scolytinae) in Oman. Eur. J. Plant Pathol. 2013, 135, 243-251. [CrossRef]

72. Soulioti, N.; Tsopelas, P.; Woodward, S. Platypus cylindrus, a vector of Ceratocystis platani in Platanus orientalis stands in Greece. For. Pathol. 2015, 45, 367-372. [CrossRef]

73. Lee, S.S. Ceratocystis wilt, a threat to Malaysian forest plantation. In Proceeding of the Wilt Disease, Wilt Disease: Risk and Threat against Acacia mangium Plantation in Malaysia, Temerloh, Malaysia, 11-12 January 2017; pp. 3-6.

74. Al-Adawi, A.O.; Barnes, I.; Khan, I.A.; Al-Subhi, A.M.; Al-Jahwari, A.A.; Deadman, M.L.; Wingfield, B.D.; Wingfield, M.J. Ceratocystis manginecans associated with a serious wilt disease of two native legume trees in Oman and Pakistan. Australas. Plant Pathol. 2013, 42, 179-193. [CrossRef]

75. Naidoo, K.; Steenkamp, E.T.; Coetzee, M.P.; Wingfield, M.J.; Wingfield, B.D. Concerted evolution in the ribosomal RNA cistron. PLoS ONE 2013, 8, e59355. [CrossRef]

76. Valdetaro, D.C.O.F.; Oliveira, L.S.S.; Guimarães, L.M.S.; Harrington, T.C.; Rodrigo, M.F.A.; Freitas, G.; Alfenas, A.C. Genetic variation, morphology, and pathogenicity of Ceratocystis fimbriata on Hevea brasiliensis in Brazil. Trop. Plant Pathol. 2015, 40, 184-192. [CrossRef]

77. Oliveira, L.S.S.; Damacena, M.B.; Guimarães, L.M.S.; Siqueira, D.L.; Alfenas, A.C. Ceratocystis fimbriata isolates on Mangifera indica have different levels of aggressiveness. Eur. J. Plant Pathol. 2016, 145, 847-856. [CrossRef]

78. McDonald, B.A.; Linde, C. Pathogen population genetics, evolutionary potential and durable resistance. Annu. Rev. Phytopathol. 2002, 40, 349-379. [CrossRef]

79. Albuquerque, F.C.; Duarte, M.L.R.; Silva, H.M. Ocorrência do mofocinzento (Ceratocystis fimbriata) da seringueira. In Proceedings of the Seminário Nacional da Seringueira, Belém, Brazil, 19-25 November 1972; pp. 125-128. 